\title{
Effect of Mg Treatment on Inclusions of X65 Pipeline Steel
}

\section{Jun Tian, Tianpeng Qu*, Deyong Wang, Huihua Wang and Xinrui E}

\author{
Shagang School of Iron and Steel, Soochow University, China
}

\begin{abstract}
Three heats of X65 pipeline steels are produced in a factory, two of which were treated with magnesium. The characteristics of inclusions in those steels were analyzed by SEM-EDS and ASPEX. And the influence of magnesium treatment on inclusions of X65 pipeline steel are studied in this paper. The results show that: (1) The oxide inclusions in non-magnesium treated steel are mainly $\mathrm{Al}_{2} \mathrm{O}_{3}$ inclusions, while the oxide inclusions are mainly $\mathrm{MgO} \cdot \mathrm{Al}_{2} \mathrm{O}_{3}$ in the steel with magnesium-treated. (2) The proportion of the small size $(1-5 \mu \mathrm{m})$ inclusions in magnesium-treated steel is relatively high, and that of the large size $(>15-\mu \mathrm{m})$ inclusions is obviously reduced. (3) The larger size inclusions are mainly $\mathrm{Al}_{2} \mathrm{O}_{3}$ and the inclusions near the low melting zone. The inclusions close to $\mathrm{MgO} \cdot \mathrm{Al}_{2} \mathrm{O}_{3}$ spinel composition have smaller size, indicating that the magnesium treatment could make the size of inclusions less and disperse the inclusions. (4) Magnesium-treated steel contained a large number of fine $\mathrm{MgO} \cdot \mathrm{Al}_{2} \mathrm{O}_{3}$ inclusions, which could provide nucleation core for the precipitation of sulfide, thus reducing the precipitation of sulfide at a grain boundary. And the number of pure $\mathrm{MnS}$ decrease after magnesium treatment.
\end{abstract}

\section{Keywords}

Magnesium treatment, Inclusion, Sulfur, Pipeline steel

\section{Introduction}

Hydrogen induced cracking $(\mathrm{HIC})$ is one of the main failure modes of pipeline steel. In recent years, oil and gas pipeline have developed to the large diameter and high pressure direction, which require pipeline steel to keep higher strength and toughness [1]. However, the higher the strength of steel, the greater the sensitivity of hydrogen-induced cracks [2]. Inclusions in steel are usually regarded as hydrogen traps. When the pipeline steel undergoes a rotting reaction in an acidic environment, the resulting hydrogen enters the steel matrix, aggregates around inclusions to produce hydrogen pressure, and eventually forms a hydrogen-induced crack at the edges of the inclusions. Therefore, inclusions in steel are one of the main reasons for the production of HIC, especially the strip of oxide inclusions and long strip MnS inclusions, have the biggest influence on anti-HIC property of the steel [3-6]. Therefore, in order to improve the pipeline steel's anti-HIC performance, it is necessary to strictly control the amount and shape of inclusions in the steel.

At present, a commonly used method for mod-

*Corresponding author: Tianpeng Qu, Shagang School of Iron and Steel, Soochow University, Suzhou 215021, PR China, Tel: +86-183-626-21026

Accepted: February 19, 2020; Published: February 21, 2020

Copyright: (C) 2020 Tian et al. This is an open-access article distributed under the terms of the Creative Commons Attribution License, which permits unrestricted use, distribution, and reproduction in any medium, provided the original author and source are credited.

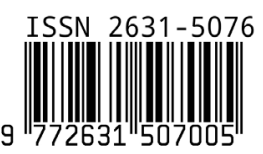

Tian et al. Int J Metall Met Phys 2020, 5:045 
ification of inclusions in pipeline steel was calcium treatment $[7,8]$, so that, the MnS inclusions in the steel are modified into spherical $\mathrm{CaS}$ inclusions and $\mathrm{CaO}-\mathrm{Al}_{2} \mathrm{O}_{3}-\mathrm{CaS}$ complex inclusions, and the $\mathrm{B}$ type inclusions are modified into low melting point of calcium aluminate inclusions, which are easy to grow up and float. However, to some extent, calcium treatment could improve the adverse effect of $\mathrm{MnS}$, but the low-melting calcium aluminate inclusions would be formed after calcium treatment. And if the low-melting calcium aluminate inclusions don't eliminate completely in time, they will form a cluster $\mathrm{CaO}-\mathrm{Al}_{2} \mathrm{O}_{3}$ inclusions in rolled metal, which seriously affect the anti-HIC performance of the product [3,9-11]. It is obvious that calcium treatment has some deficiencies in modification of inclusions in pipeline steel.

Magnesium treatment could make the inclusions small and dispersed [12-14], and MnS inclusions also would be modified to complex sulfide by magnesium treatment [15-17]. In view of the advantages of magnesium treatment, this paper carries out the magnesium treatment on $X 65$ pipeline steel, and the effect of $\mathrm{Mg}$ on inclusions are analyzed in pipeline steel. The results could provide a reference for the application of magnesium treatment of pipeline steel.

\section{Experimental}

Three heats of industrial trials are performed in a 200t ladle and recorded as No.1, No.2 and No.3 respectively. The production route is "BOF(basic oxygen furnace) $\rightarrow$ LF(ladle furnace) $\rightarrow \mathrm{RH} \rightarrow$ magnesium treatment $\rightarrow$ soft blowing by $\mathrm{Ar}$ gas $\rightarrow \mathrm{CC}$ (continuous casting)". In particular, magnesium treatment was not applied to heat No. 1 but the other process is identical. The details of the process practices could be described as follows.

During tapping of BOF, synthetic slag and ferroalloys with aluminum are added into the stream of liquid steel. After that, the melt is stirred by argon to made the composition and temperature homogenized. And then the melt is transported to LF refining station, in which high basicity slag is used and aluminum is added to decrease the oxygen and sulfur of the steel. After $40 \mathrm{~min}$, the melt is delivered to $\mathrm{RH}$ refining station, at this station the liquid steel is treated at the pressure of $67 \mathrm{~Pa}$ for $20 \mathrm{~min}$, and then $120 \mathrm{~m}$ and $220 \mathrm{~m}$ magnesium wire are inserted into the ladle by a wire-feeding mechanism for Heat 2 and 3 respectively. After magnesium treatment, the molten steel is gently stirred for $10 \mathrm{~min}$ to promote the inclusions floating upward. And then the ladle is transferred to the continuous caster.

The steel samples are taken from casting billet. The contents of $\mathrm{C}$ and $\mathrm{S}$ of the samples are analyzed with infrared analysis. The concentrations of $\mathrm{Si}, \mathrm{Mn}, \mathrm{P}, \mathrm{Mg}, \mathrm{Nb}, \mathrm{V}, \mathrm{Ti}$, Als (dissolved aluminum) and $O$ (dissolved oxygen) are determined using ICP-OES (inductively coupled plasma-atomic emission spectroscopy). The $\mathrm{N}$ content is analyzed using thermal conductance. The results are shown in Table 1. All the samples are cross-sectioned and polished, and then morphology and composition of inclusions are analyzed by SEM(Scanning Electron Microscopy), EDS (Energy Dispersive Spectrometer) and ASPEX (Aspex scanning electron microscopes).

\section{Experiment Results}

\section{Morphology and composition of the inclusion}

The compositions and morphologies of inclusions in samples are analyzed by SED-EDS. Figure 1 is an SEM photograph of inclusions in the sample of heat No.1. These inclusions are mainly $\mathrm{Al}_{2} \mathrm{O}_{3}$ inclusions (Figure 1a) and $\mathrm{MnS}$ inclusions with oxide as nucleus (Figure 1b). Figure 2 and Figure 3 are SEM photographs of inclusions of steel with different $\mathrm{Mg}$ contents, respectively. As can be seen from the figure, the inclusions in magnesium-treated steel are mainly $\mathrm{MgO} \cdot \mathrm{Al}_{2} \mathrm{O}_{3}$ inclusions and $\mathrm{MnS}$ inclusions precipitated with $\mathrm{MgO} \cdot \mathrm{Al}_{2} \mathrm{O}_{3}$ spinel, and $\mathrm{MnS}$ inclusions contain a small amount of $\mathrm{Mg}$.

Table 1: Chemical composition of experimental steels.

\begin{tabular}{|l|l|l|l|l|l|l|l|l|l|l|l|l|}
\hline Heat & \multicolumn{9}{|l|}{ Chemical composition, wt \% } \\
\hline & $\mathbf{C}$ & $\mathbf{S i}$ & $\mathbf{M n}$ & $\mathbf{P}$ & $\mathbf{S}$ & $\mathbf{N b}$ & $\mathbf{V}$ & $\mathbf{T i}$ & Als & $\mathbf{M g}$ & $\mathbf{T . 0}$ & $\mathbf{N}$ \\
\hline No.1 & 0.060 & 0.187 & 1.41 & 0.010 & 0.009 & 0.037 & 0.046 & 0.0207 & 0.0256 & - & 0.0051 & 0.0029 \\
\hline No.2 & 0.071 & 0.190 & 1.39 & 0.008 & 0.007 & 0.050 & 0.045 & 0.0250 & 0.0470 & 0.0013 & 0.0056 & 0.0041 \\
\hline No.3 & 0.077 & 0.190 & 1.45 & 0.006 & 0.008 & 0.053 & 0.044 & 0.0210 & 0.0380 & 0.0024 & 0.0053 & 0.0015 \\
\hline
\end{tabular}




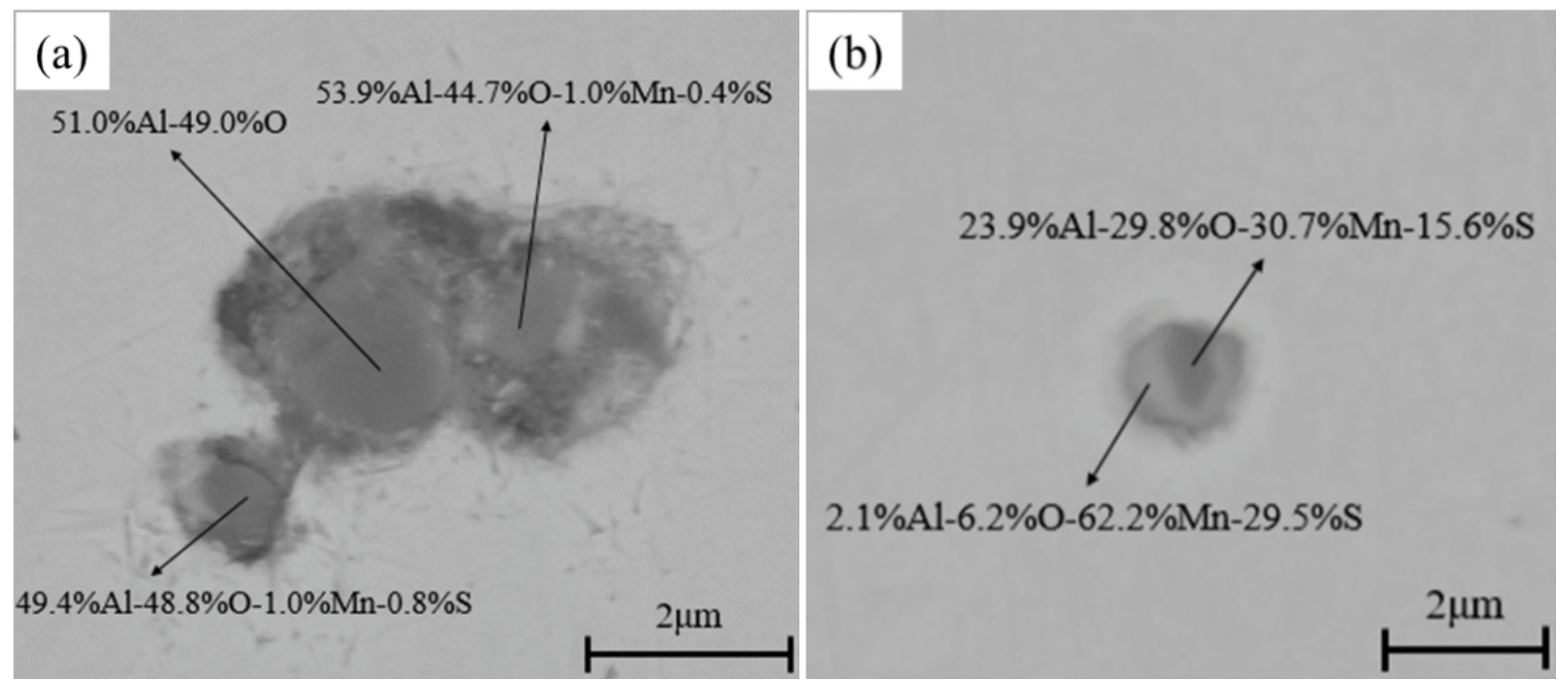

Figure 1: Inclusion morphologies of heat No.1.

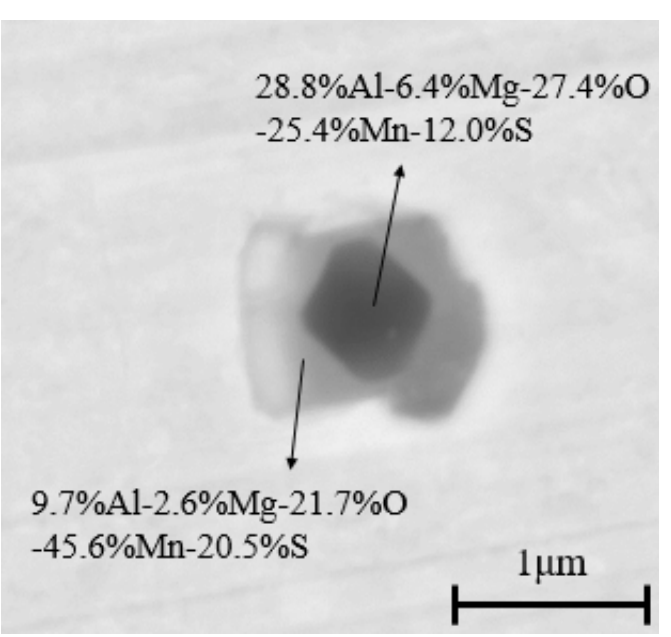

Figure 2: Inclusion morphology of heat No.2.

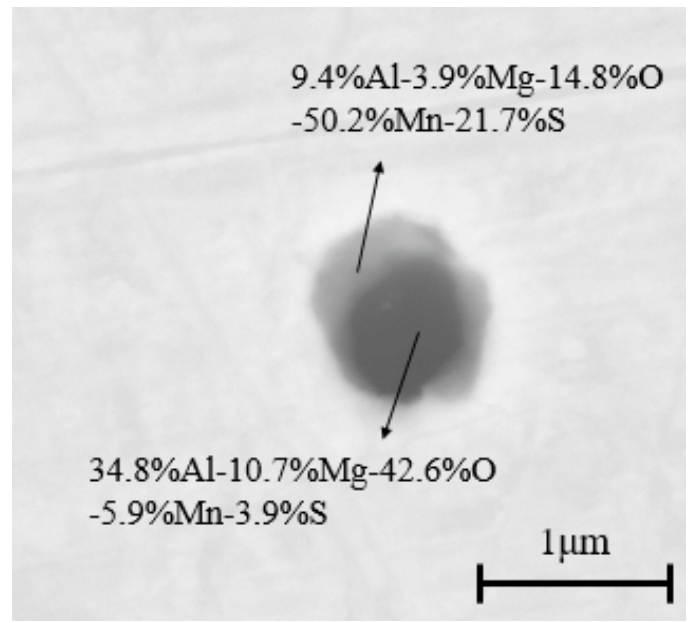

Figure 3: Inclusion morphology of heat No.3.

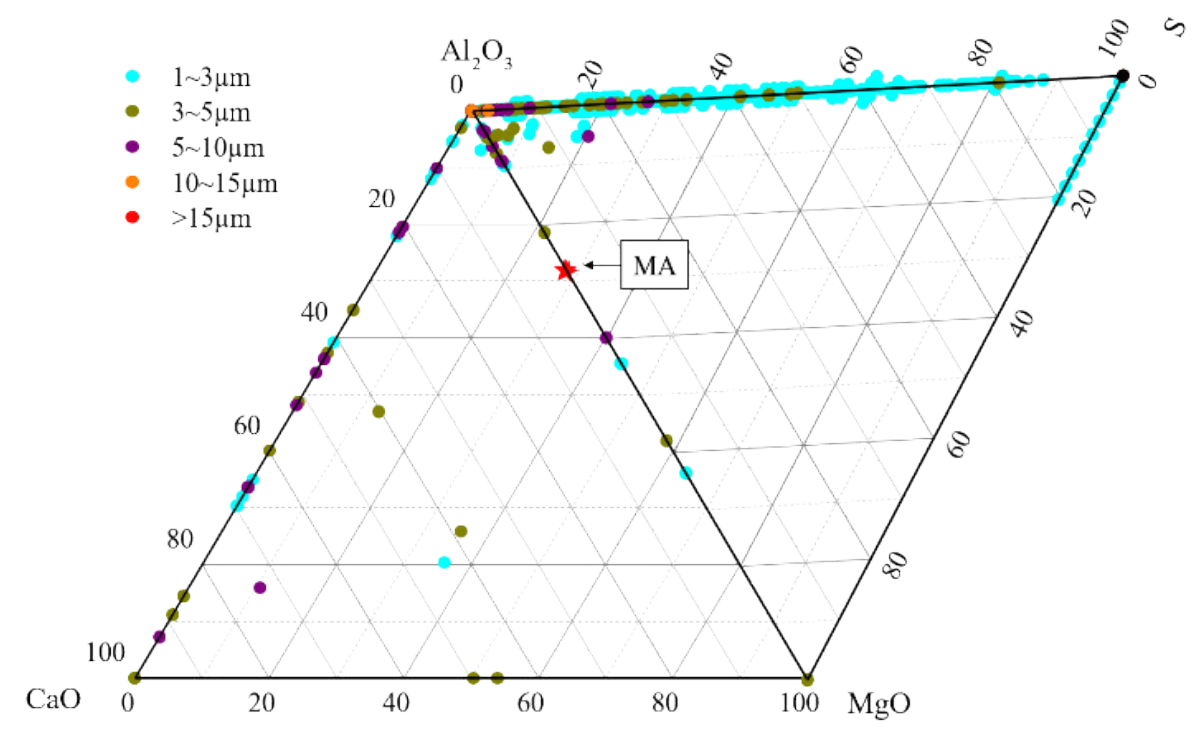

Figure 4: Composition distribution of inclusions in the heat No.1. 


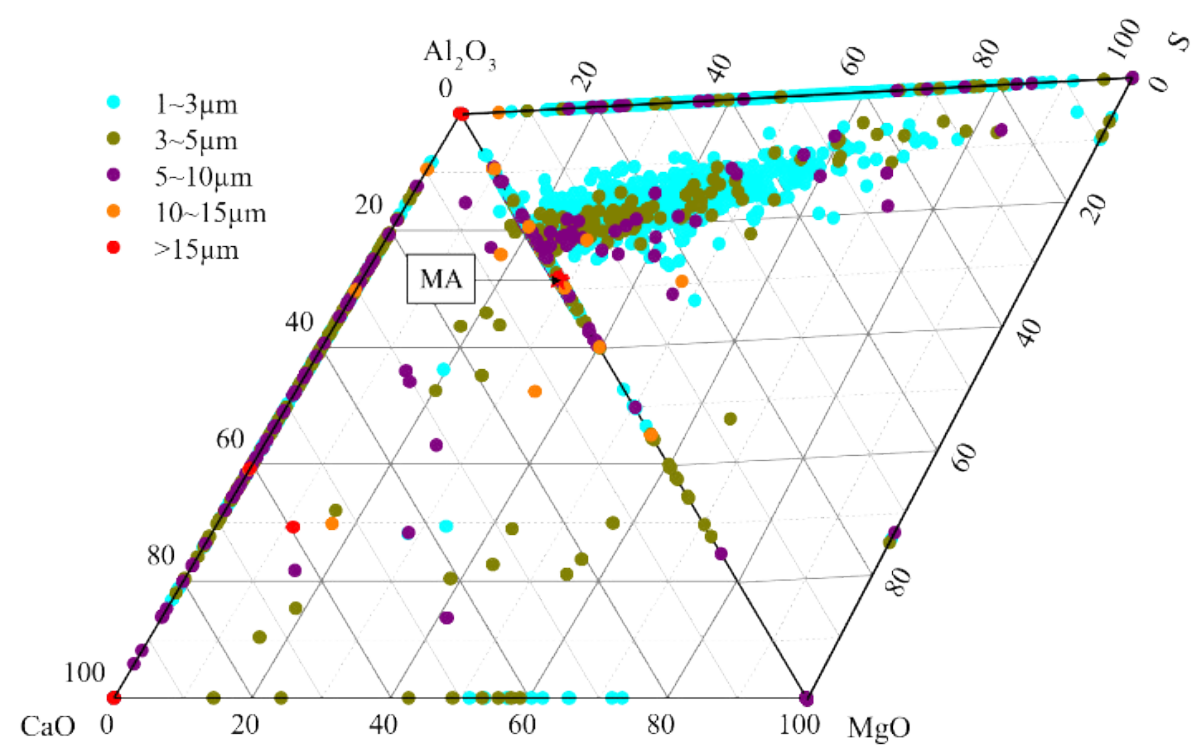

Figure 5: Composition distribution of inclusions in the heat No.2.

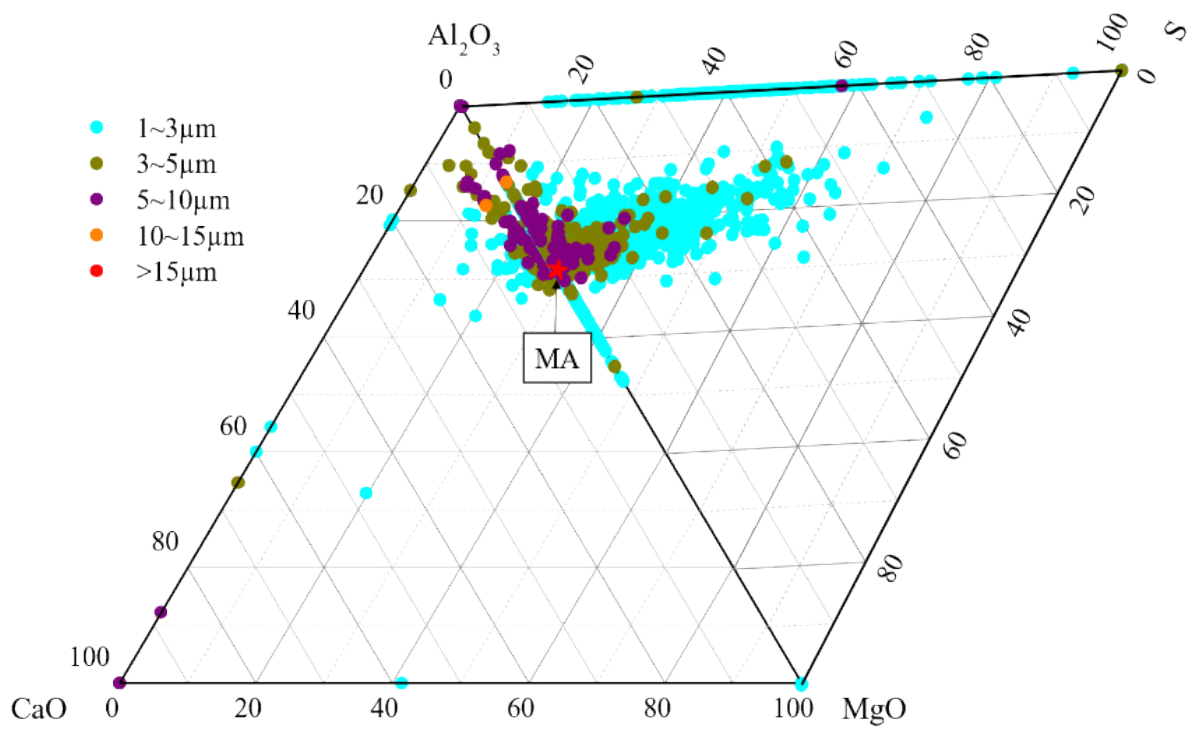

Figure 6: Composition distribution of inclusions in the heat No.3.

Quantitative analysis of the types of inclusions in the steel is made by ASPEX. Figure 4, Figure 5 and Figure 6 are the results of quantitative analysis, where $S$ indicates the sulfur content of the inclusions, and $\mathrm{MA}$ represents the $\mathrm{MgO} \cdot \mathrm{Al}_{2} \mathrm{O}_{3}$ spinel ( $\mathrm{M}$ means $\mathrm{MgO}$, A means $\mathrm{Al}_{2} \mathrm{O}_{3}$ ). It can be seen from Figure 4 that the inclusions of the heat NO.1 are mainly calcium aluminates and compound inclusion of $\mathrm{Al}_{2} \mathrm{O}_{3}$ and sulfide. And there are a small amount of $\mathrm{MgO}-\mathrm{CaO}-\mathrm{Al}_{2} \mathrm{O}_{3}$ inclusions in this sample. The Figure 5 shows that the type of inclusions are mainly $\mathrm{MgO}-\mathrm{Al}_{2} \mathrm{O}_{3}$-sulfide compound inclusion and $\mathrm{MgO}-\mathrm{CaO}-\mathrm{Al}_{2} \mathrm{O}_{3}$ inclusions in the heat No.2. And these inclusion composition are close to the
MA spinel composition, and most of the sulfides are $\mathrm{MgO}-\mathrm{Al}_{2} \mathrm{O}_{3}$ inclusions Core nucleation. It can be seen from Figure 6 that most of the inclusions in the heat $\mathrm{No} .3$ are also $\mathrm{MgO}-\mathrm{CaO}-\mathrm{Al}_{2} \mathrm{O}_{3}$ inclusions and $\mathrm{MgO}-\mathrm{Al}_{2} \mathrm{O}_{3}$-sulfide compound inclusion, furthermore, those inclusion composition are closer to the MA spinel composition than that of the other heat.

Figure 7, Figure 8 and Figure 9 are types of inclusion in the heat No.1, No.2 and No.3, respectively. In the figure, $\mathrm{A}$ means $\mathrm{Al}_{2} \mathrm{O}_{3}, \mathrm{M}$ means $\mathrm{MgO}$, and $\mathrm{C}$ means $\mathrm{CaO}$. It can be seen from those figures, the inclusions of the heat No.1 are mainly MnS-A (42.52\%), MnS (23.36\%) and A (14.20\%), 


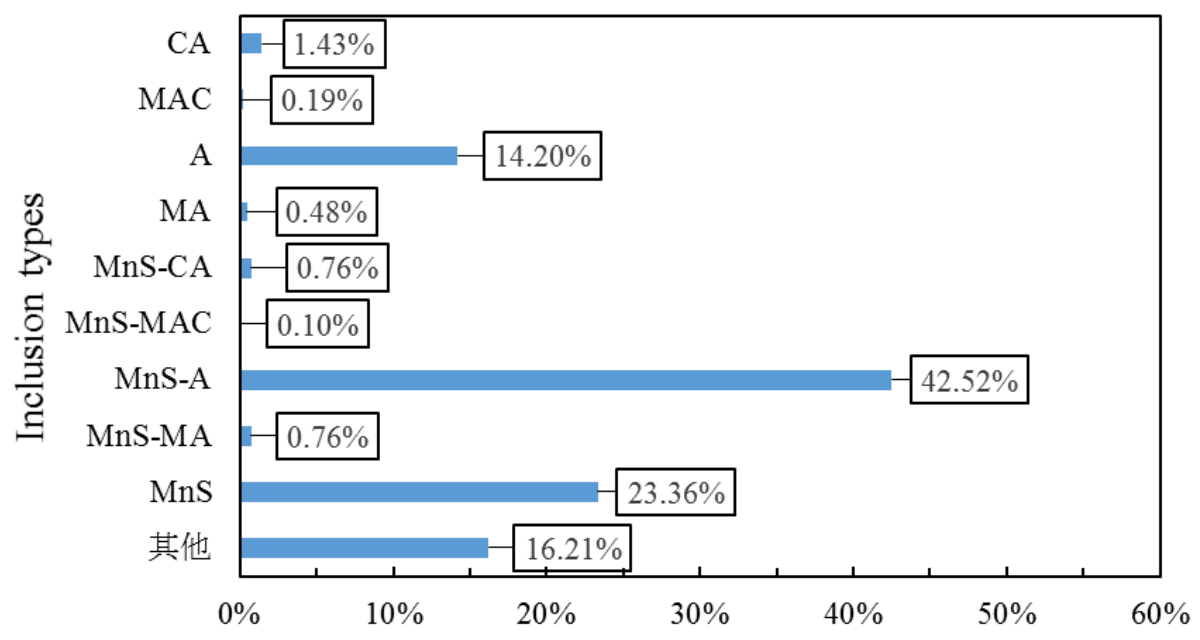

Quantity percentage $\mathrm{M}: \mathrm{MgO}, \mathrm{A}: \mathrm{Al}_{2} \mathrm{O}_{3}, \mathrm{C}: \mathrm{CaO}$

Figure 7: Inclusion types of the heat No.1.

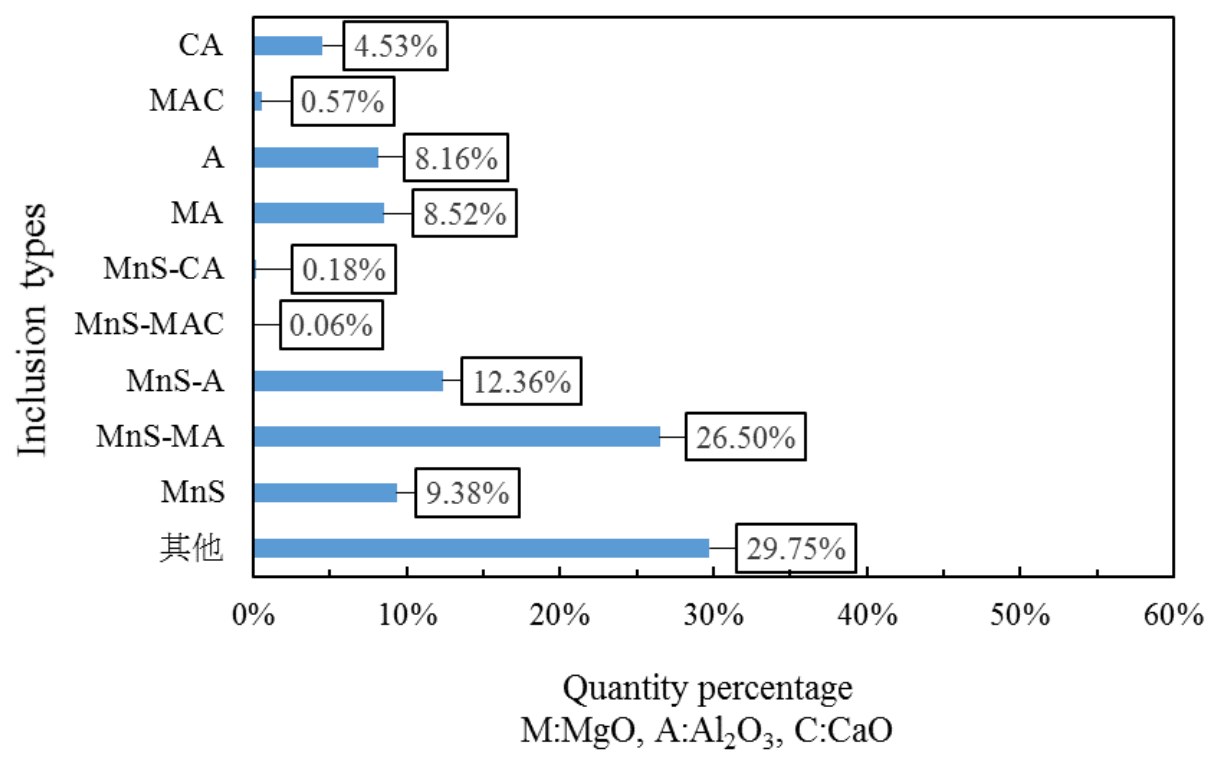

Figure 8: Inclusion types of the heat No.2.

Table 2: Size distribution of inclusions in the steels.

\begin{tabular}{|c|c|c|c|c|c|c|}
\hline \multirow[t]{2}{*}{ Heat } & \multirow{2}{*}{$\begin{array}{l}\text { Scanning } \\
\text { area, } \mu \mathrm{m}^{2}\end{array}$} & \multicolumn{5}{|c|}{$\begin{array}{l}\text { The percentage of inclusions with different particle sizes accounted for the total } \\
\text { number of inclusions }\end{array}$} \\
\hline & & 1-3 $\mu \mathrm{m}$ & 3-5 $\mu \mathrm{m}$ & 5-10 $\mu \mathrm{m}$ & $10-15 \mu \mathrm{m}$ & $>15 \mu \mathrm{m}$ \\
\hline No.1 & 16000000 & $81.66 \%$ & $12.78 \%$ & $4.94 \%$ & $0.42 \%$ & $0.21 \%$ \\
\hline No.2 & 12000000 & $84.54 \%$ & $13.07 \%$ & $2.10 \%$ & $0.19 \%$ & $0.10 \%$ \\
\hline No.3 & 16000000 & $85.70 \%$ & $11.82 \%$ & $2.44 \%$ & $0.05 \%$ & $0.00 \%$ \\
\hline
\end{tabular}

after magnesium treatment, the inclusions are mainly MnS-MA (26.50\%), MnS-A (12.36\%), MnS $(9.38 \%), M A(8.52 \%)$ and $A(8.16 \%)$ in the heat No.2, and mainly MnS-MA (42.01\%), MA (12.91\%)
MnS-A (7.60\%), MnS 5.47\%), and A (5.00\%) in the heat No.3. And proportion of the pure MnS inclusion decrease with magnesium content increase. 


\section{Size of inclusions}

The size of the inclusions in the samples was quantitatively analyzed by ASPEX, and the results are shown in Table 2. It can be seen from the table, in the steel with magnesium treatment, the number of inclusions with small particle size (1-3 $\mu \mathrm{m})$ increases. Since more than $90 \%$ of the inclusions in the steel have a particle size of less than $5 \mu \mathrm{m}$. Statistical classification of the inclusions is carried out, and the results are shown in Figure 10. As can be seen from this figure, after the magnesium treatment, the proportion of inclusions of the particle size of 1-2 $\mu \mathrm{m}$ increases.

\section{Analysis and Discussion}

\section{Effect of magnesium treatment on oxide inclu- sions of steel}

When $\mathrm{Mg}$ is added to the steel, the following reactions occur [18]:

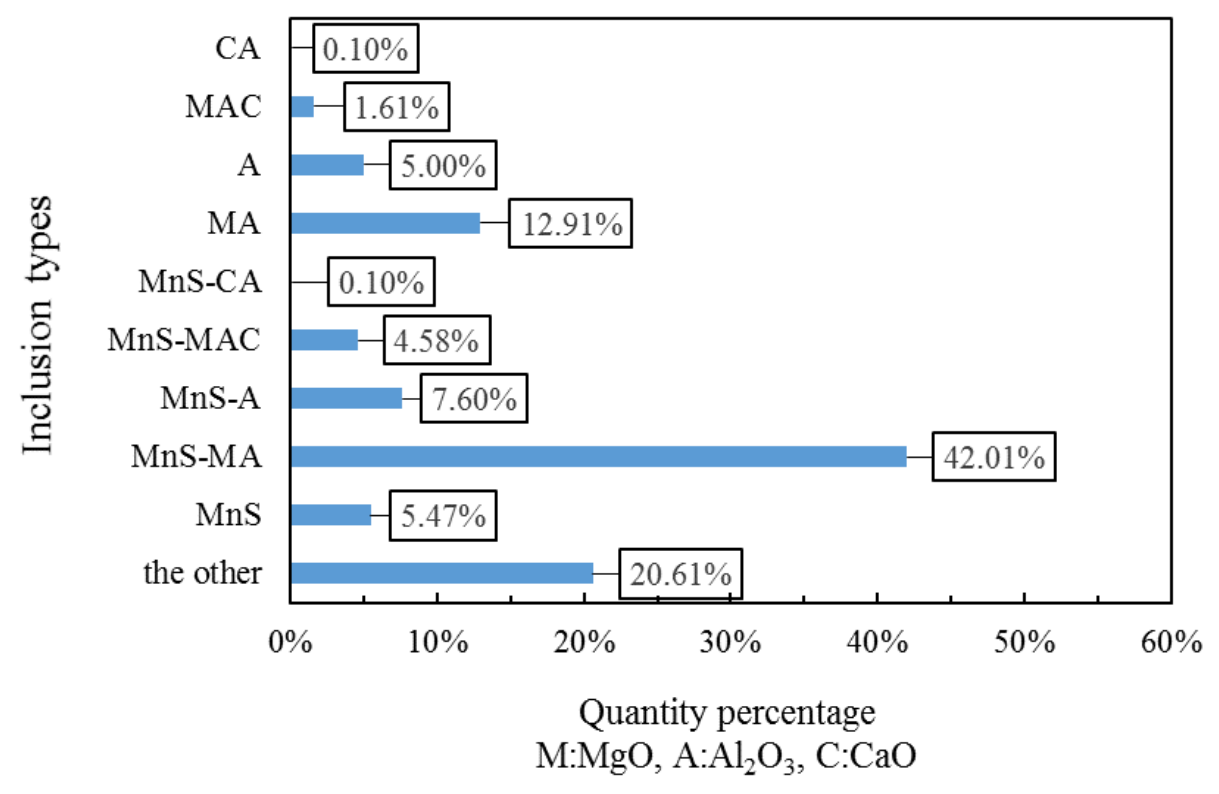

Figure 9: Inclusion types of the heat No.3.

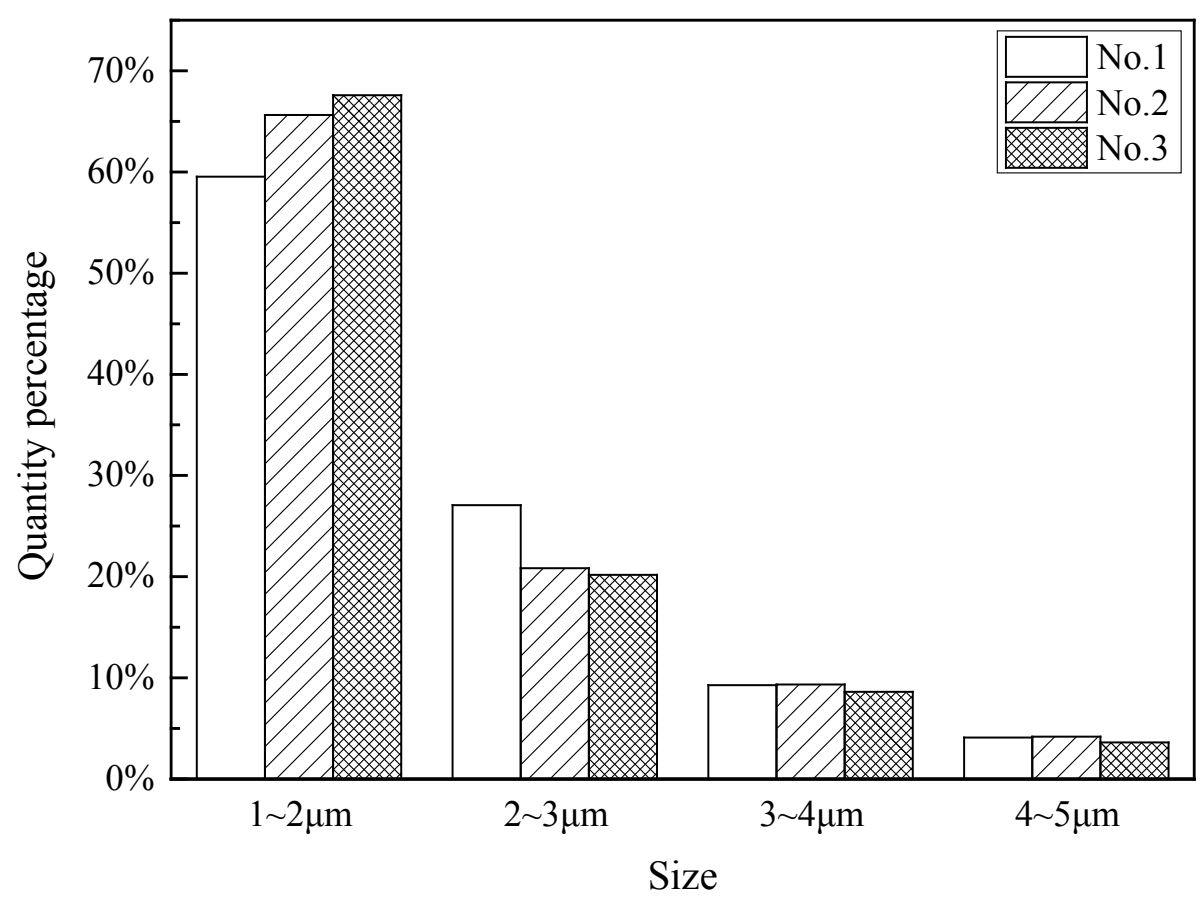

Figure 10: Inclusion size distribution. 
$\begin{array}{ll}\mathrm{Al}_{2} \mathrm{O}_{3}(\mathrm{~s})=2[\mathrm{Al}]+3[\mathrm{O}] & \mathrm{G}^{0}=867366-223 \mathrm{~T} \\ \mathrm{MgO}(\mathrm{s})=[\mathrm{Mg}]+[\mathrm{O}] & \mathrm{G}^{0}=90000+82 \mathrm{~T}\end{array}$

$\mathrm{MgO} \cdot \mathrm{Al}_{2} \mathrm{O}_{3}(\mathrm{~s})=\mathrm{MgO}(\mathrm{s})+\mathrm{Al}_{2} \mathrm{O}_{3}(\mathrm{~s}) \quad \mathrm{G}^{0}=20740+$ $11.57 \mathrm{~T}(3)$

$\mathrm{Al}_{2} \mathrm{O}_{3}, \mathrm{MgO}$ and $\mathrm{MgO} \cdot \mathrm{Al}_{2} \mathrm{O}_{3}$ are regarded as pure substances, then their activities are 1 . The activities

Table 3: Interaction coefficients $\left(e_{i}^{j}\right)$ of elements in molten steel at $1873 \mathrm{~K}$.

\begin{tabular}{|c|c|c|c|}
\hline j & Al & Mg & $S$ \\
\hline C & 0.0910 & -0.240 & 0.110 \\
\hline Si & 0.0056 & -0.088 & 0.063 \\
\hline$M n$ & 0.0035 & 0.024 & -0.026 \\
\hline $\mathbf{P}$ & 0.0330 & - & 0.029 \\
\hline$S$ & 0.0300 & -1.380 & -0.028 \\
\hline Nb & - & - & -0.013 \\
\hline$v$ & - & - & -0.016 \\
\hline $\mathrm{Ti}$ & 0.0040 & -0.510 & -0.072 \\
\hline Al & 0.0450 & -0.120 & 0.035 \\
\hline Mg & -1.9800 & -0.047 & -0.026 \\
\hline 0 & -6.6000 & -289 & -0.270 \\
\hline $\mathbf{N}$ & -0.053 & - & 0.010 \\
\hline
\end{tabular}

of other substances are calculated using equations (4) and (5), where the interaction coefficients of the elements are shown in Table $3[5,19,20]$.

$$
\begin{aligned}
& \alpha_{\mathrm{i}}=f_{\mathrm{i}} \cdot \mathrm{w}[\mathrm{i}] \\
& \operatorname{lgf}_{\mathrm{i}}=\sum_{\mathrm{j}=2}^{\mathrm{n}} \mathrm{e}_{\mathrm{i}}^{\mathrm{j}}[\% \mathrm{j}]
\end{aligned}
$$

The equilibrium phase diagram of $\mathrm{MgO}-\mathrm{MgO} \cdot \mathrm{A}-$ $\mathrm{I}_{2} \mathrm{O}_{3}-\mathrm{Al}_{2} \mathrm{O}_{3}$ at $1873 \mathrm{~K}$ can be calculated by the Matlab software, as shown in Figure 11. As can be seen from the figure, after magnesium treatment, the content of $[\mathrm{Mg}]$ and $[\mathrm{Al}]$ in the steel is in the range of $\mathrm{MgO} \cdot \mathrm{Al}_{2} \mathrm{O}_{3}$, so inclusions of the steel added magnesium are mainly $\mathrm{MgO} \cdot \mathrm{Al}_{2} \mathrm{O}_{3}$, which is consistent with the experimental results. Classify the oxide inclusions in the steel, which is shown in Table 4, and every oxide type include pure oxide and MnS-oxide. In the heat No.1 without $\mathrm{Mg}$, the inclusions in the steel are mainly $\mathrm{Al}_{2} \mathrm{O}_{3}$ inclusions, the proportion is $93.85 \%$, and that of $\mathrm{MgO}-\mathrm{Al}_{2} \mathrm{O}_{3}$ inclusion are only $2.05 \%$. After magnesium treatment, the proportion of $\mathrm{MgO}-\mathrm{Al}_{2} \mathrm{O}_{3}$ inclusions in the steel are increased to $57.53 \%$ and $74.30 \%$ respectively, in the heat No.2 and No. 3, and that of $\mathrm{Al}_{2} \mathrm{O}_{3}$ inclusion in these heat are reduced to $33.71 \%$ and $17.04 \%$, respectively.

Calculate the average composition of the oxide

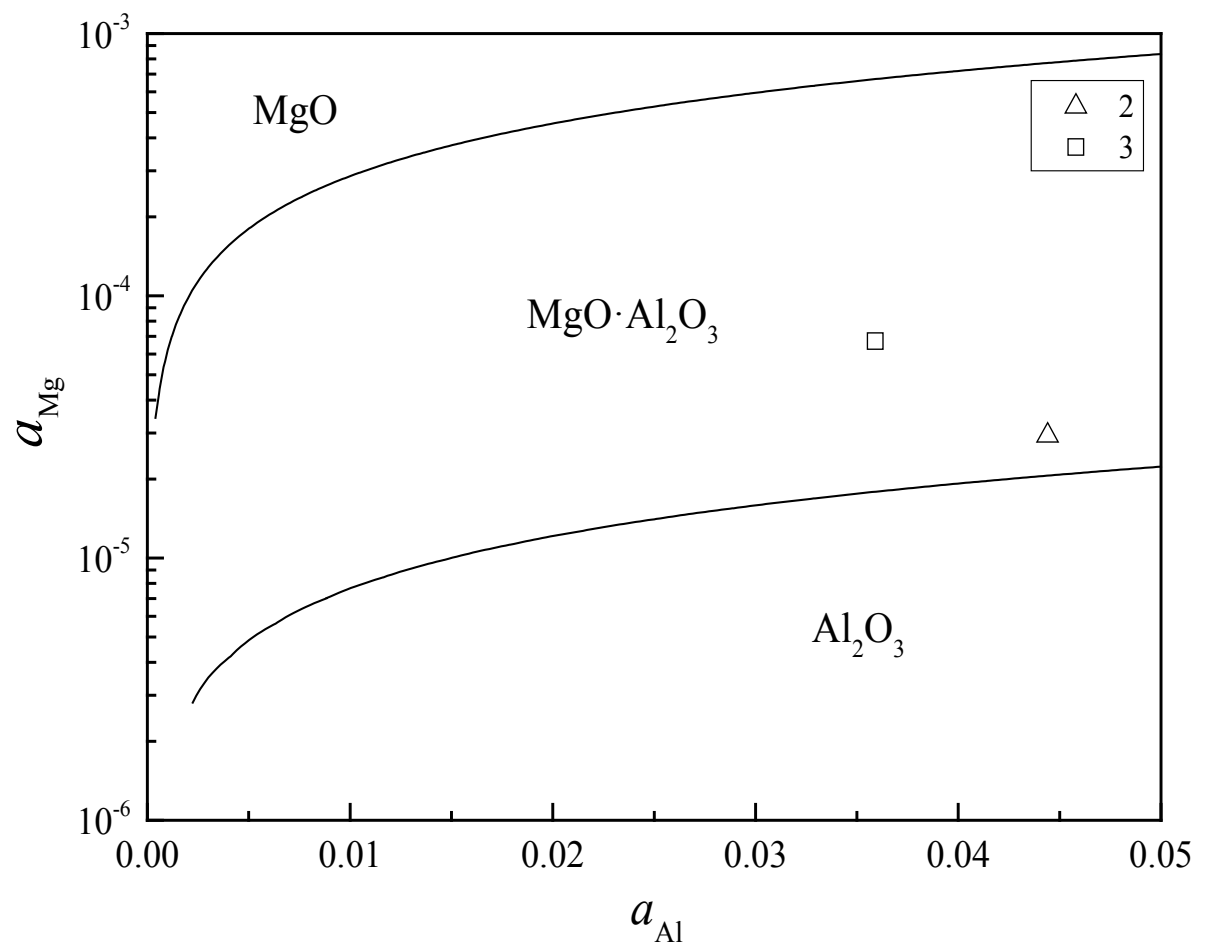

Figure 11: The equilibrium phase diagram of $\mathrm{MgO}-\mathrm{MgO} \cdot \mathrm{Al}_{2} \mathrm{O}_{3}-\mathrm{Al}_{2} \mathrm{O}_{3}$ at $1873 \mathrm{~K}$. 
Table 4: The proportion of oxide inclusions in different types of steel.

\begin{tabular}{|c|c|c|c|c|}
\hline \multirow{2}{*}{ Heat } & \multicolumn{4}{|c|}{ The type of oxide inclusion } \\
\hline & $\mathrm{Al}_{2} \mathrm{O}_{3}$ & $\mathrm{MgO}-\mathrm{Al}_{2} \mathrm{O}_{3}$ & $\mathrm{CaO}-\mathrm{MgO}-\mathrm{Al}_{2} \mathrm{O}_{3}$ & $\mathrm{CaO}-\mathrm{Al}_{2} \mathrm{O}_{3}$ \\
\hline No.1 & $93.85 \%$ & $2.05 \%$ & $0.47 \%$ & $3.63 \%$ \\
\hline No.2 & $33.71 \%$ & $57.53 \%$ & $1.03 \%$ & $7.73 \%$ \\
\hline No.3 & $17.04 \%$ & 74.30\% & $8.38 \%$ & $0.28 \%$ \\
\hline
\end{tabular}

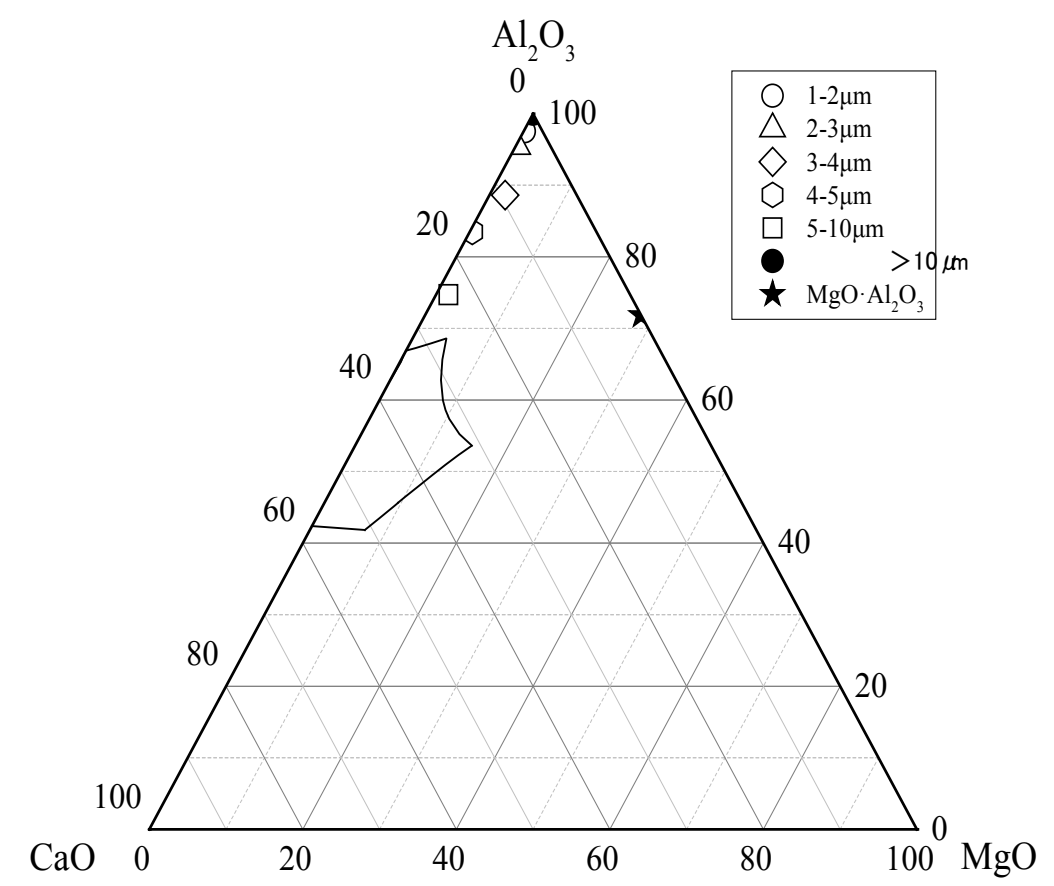

Figure 12: The average composition of oxide inclusions in the range of different particle sizes of the heat No.1.

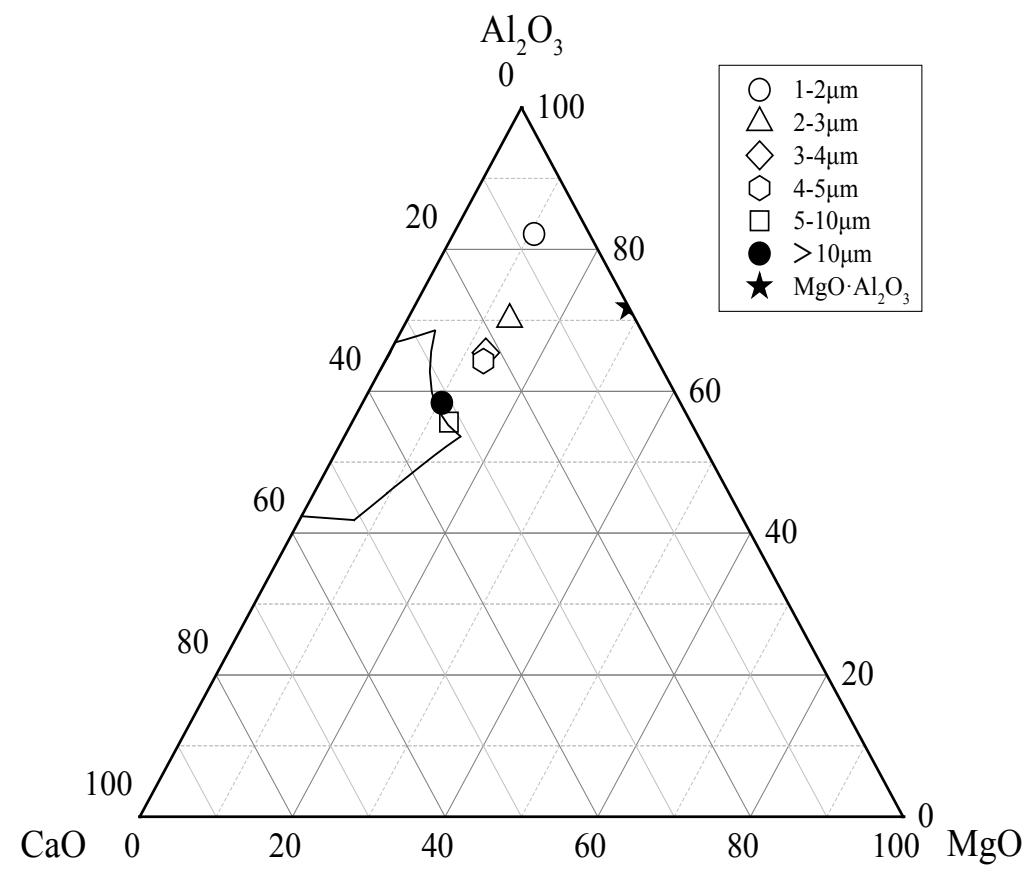

Figure 13: The average composition of oxide inclusions in the range of different particle sizes of the heat No.2. 


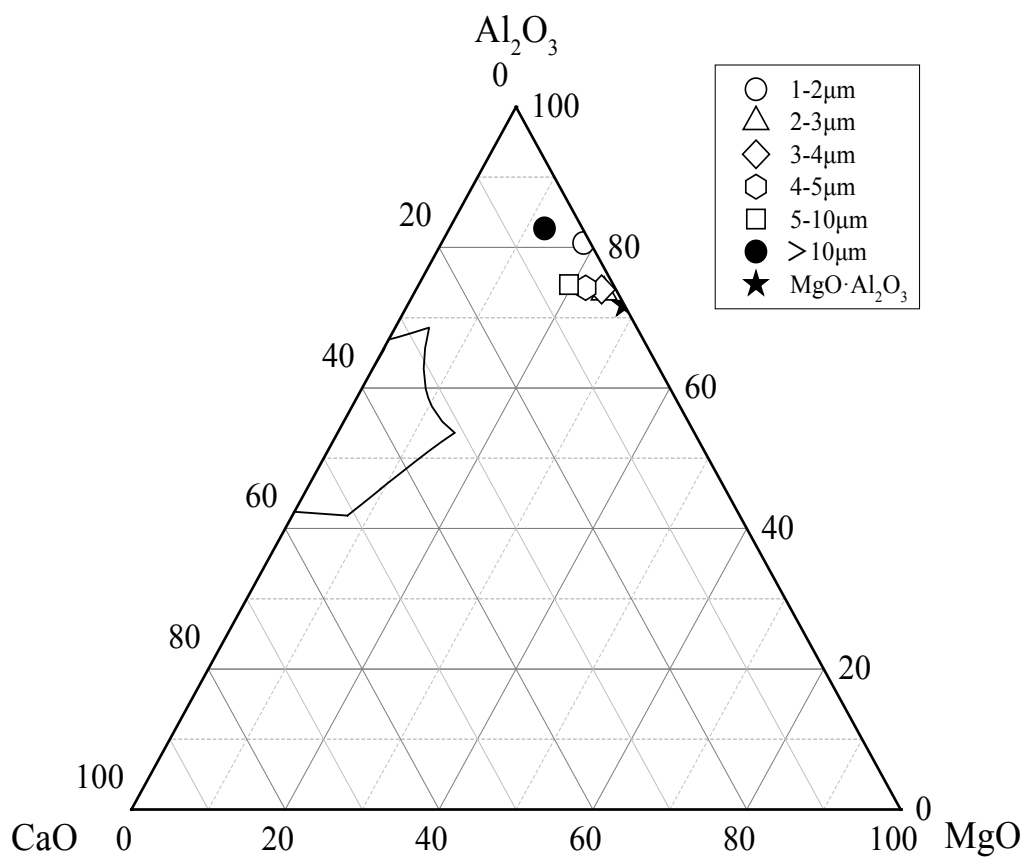

Figure 14: The average composition of oxide inclusions in the range of different particle sizes of the heat No.3.

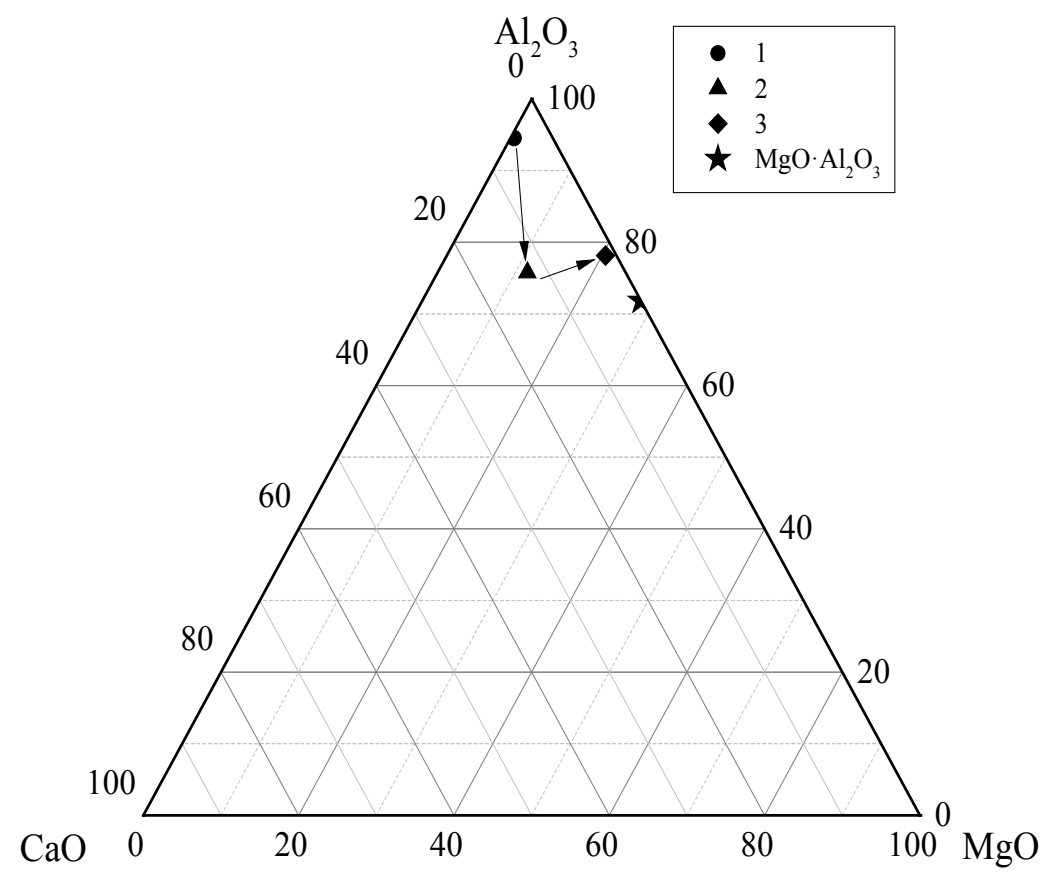

Figure 15: The changing path of the inclusion composition.

inclusions in the different particle size ranges and label them in the phase diagram, as shown in Figure 12, Figure 13 and Figure 14. The area surrounded by the broken line in the figure is the region of the melting point below $1873 \mathrm{~K}$ which is calculated by the Factsage 7.2 software. From the figure, the larger particle size of the inclusions are mainly $\mathrm{Al}_{2} \mathrm{O}_{3}$ inclusions (Figure 12) and the inclusions near the area of low melting point (Figure 13 and Figure 14). The inclusions in these two regions tend to aggregate and grow, and if they do not float to the surface in time, they will stay in the steel. As can be seen from Figure 13, the size of inclusions closed to $\mathrm{MgO} \cdot \mathrm{Al}_{2} \mathrm{O}_{3}$ spinel is smaller since it is not polymerize in the molten steel and easy to disperse in the steel $[12-14]$. The average composition of the ox- 


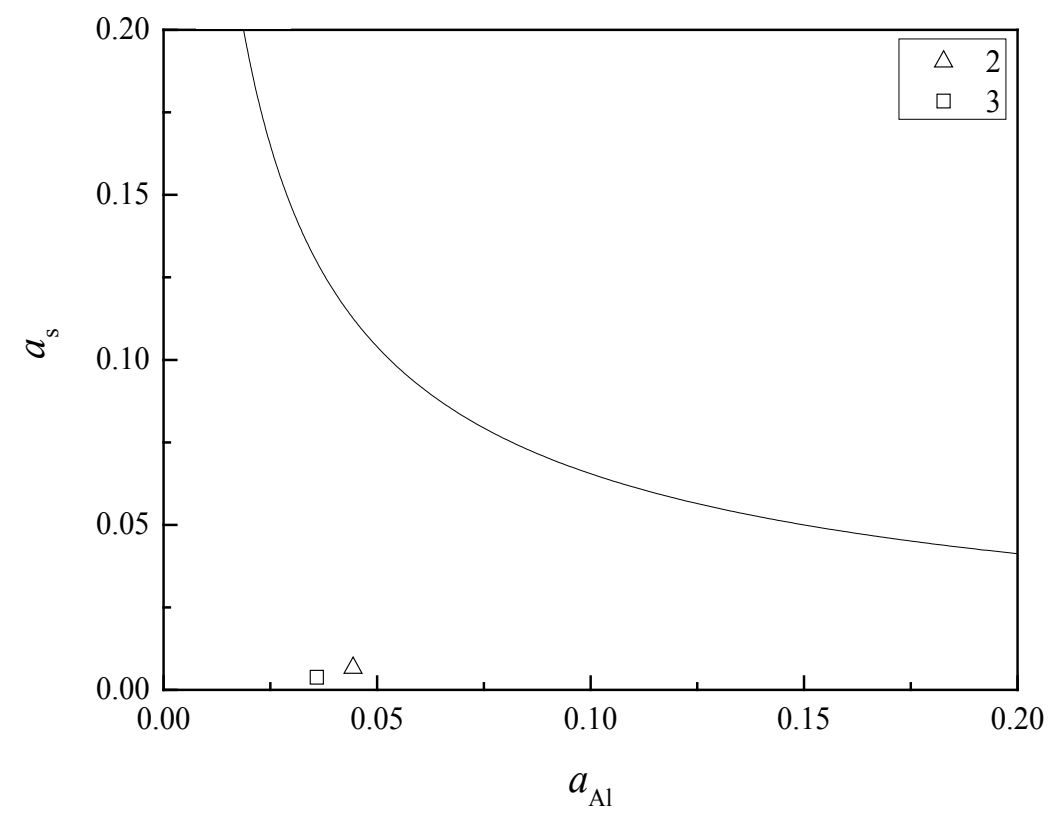

Figure 16: The equilibrium phase diagram of $\mathrm{MgO}-\mathrm{MgO} \cdot \mathrm{Al}_{2} \mathrm{O}_{3}-\mathrm{MgS}$, at $1873 \mathrm{~K}$.

ide inclusions in the three heat steel are labeled in the ternary phase diagram, as shown in Figure 15. From the figure, with the increase of $\mathrm{Mg}$ content in the steel, the composition of the oxide inclusions is constantly approaching to the spinel. Therefore, the proportion of the small size inclusions in the heat No.3 is the largest (Figure 10 and Table 2).

\section{Effect of magnesium treatment on sulfide in- clusions in steel}

The formation of sulfides in steel can be expressed by the following formula [5]:

$[\mathrm{Mg}]+[\mathrm{S}]=\mathrm{MgS}(\mathrm{s}) \quad \mathrm{G}^{0}=-522080+201.02 \mathrm{~T}$

$[\mathrm{Mn}]+[\mathrm{S}]=\mathrm{MnS}(\mathrm{s}) \quad \mathrm{G}^{0}=-167612+88.7 \mathrm{~T}$

Eq. (8) is determined by linear combination based on the thermodynamic data and Eq. (1) to Eq. (3) and Eq. (6).

$$
\begin{gathered}
\mathrm{MgO} \cdot \mathrm{Al}_{2} \mathrm{O}_{3}(\mathrm{~s})+3 \mathrm{MgS}(\mathrm{s})=4 \mathrm{MgO}(\mathrm{s})+3[\mathrm{~S}]+2[\mathrm{Al}] \\
\mathrm{G}^{0}=2184422-1060 \mathrm{~T} \\
\mathrm{~K}=\frac{a_{\mathrm{MgO}}^{4} \cdot a_{\mathrm{S}}^{3} \cdot a_{\mathrm{Al}}^{2}}{a_{\mathrm{MgO} \cdot \mathrm{Al} 2 \mathrm{O} 3} \cdot a_{\mathrm{MgS}}^{3}}
\end{gathered}
$$

$\mathrm{MgO} \cdot \mathrm{Al}_{2} \mathrm{O}_{3}, \mathrm{MgS}$ and $\mathrm{MgO}$ are regarded as pure substances, then their activities are 1 . The equilibrium phase diagram of $\mathrm{MgO}-\mathrm{MgO} \cdot \mathrm{Al}_{2} \mathrm{O}_{3}-\mathrm{MgS}$ at 1873 $\mathrm{K}$ can be calculated using the Matlab software. The value of $\alpha_{\mathrm{Al}}$ and $\alpha_{\mathrm{s}}$ can be calculated using Wagner's equation (Eq. (4)) and Eq. (5) according to the chemical compositions and thermodynam- ic data, listed in Table 1 and Table 3, respectively. And the calculation results are shown in Figure 16. From the figure, the composition points of the steel treated by magnesium are below the MgO$\mathrm{MgO} \cdot \mathrm{Al}_{2} \mathrm{O}_{3}-\mathrm{MgS}$ equilibrium line. Therefore, there are no single $\mathrm{MgO}$ inclusions in the steel, which is consistent with the previous analysis results. There will be MgS or (Mn.Mg) S inclusions in the steel. The high temperature anti-deforming capability of this kind of sulfide is higher than that of pure MnS, which can reduce the deformation degree during the rolling process, so as to avoid the form of long strips in the final product, and improve the anti-HIC performance of the pipeline steel.

The liquidus temperature $\left(T_{L}\right)$ and solidus temperature $\left(T_{\text {sol }}\right)$ of the steel is calculated by the following formulas (Eq.(10) and Eq.(11)) [21], and the critical precipitation temperature of $\mathrm{MnS}$ can be calculated using the Matlab software. Figure 17 is changes in critical precipitation temperature of $\mathrm{MnS}$ and solidus temperature $\left(\mathrm{T}_{\text {sol }}\right)$ of the steel with $\mathrm{Mn}$ content and $\mathrm{S}$ content. The composition of the steel also are plotted in the figure. As can be seen from the figure, the critical precipitation temperature of $\mathrm{MnS}$ in every heat are lower than the solidus temperature, thus, MnS could not be formed in the experimental steel over the solidus temperature, and the MnS must be precipitated during solidification process because of the segregation.

$$
\mathrm{T}_{\text {Liq }}\left({ }^{\circ} \mathrm{C}\right)=1536-83[\% \mathrm{C}]-7.8[\% \mathrm{Si}]-5[\% \mathrm{Mn}+\% \mathrm{Cu}]-
$$



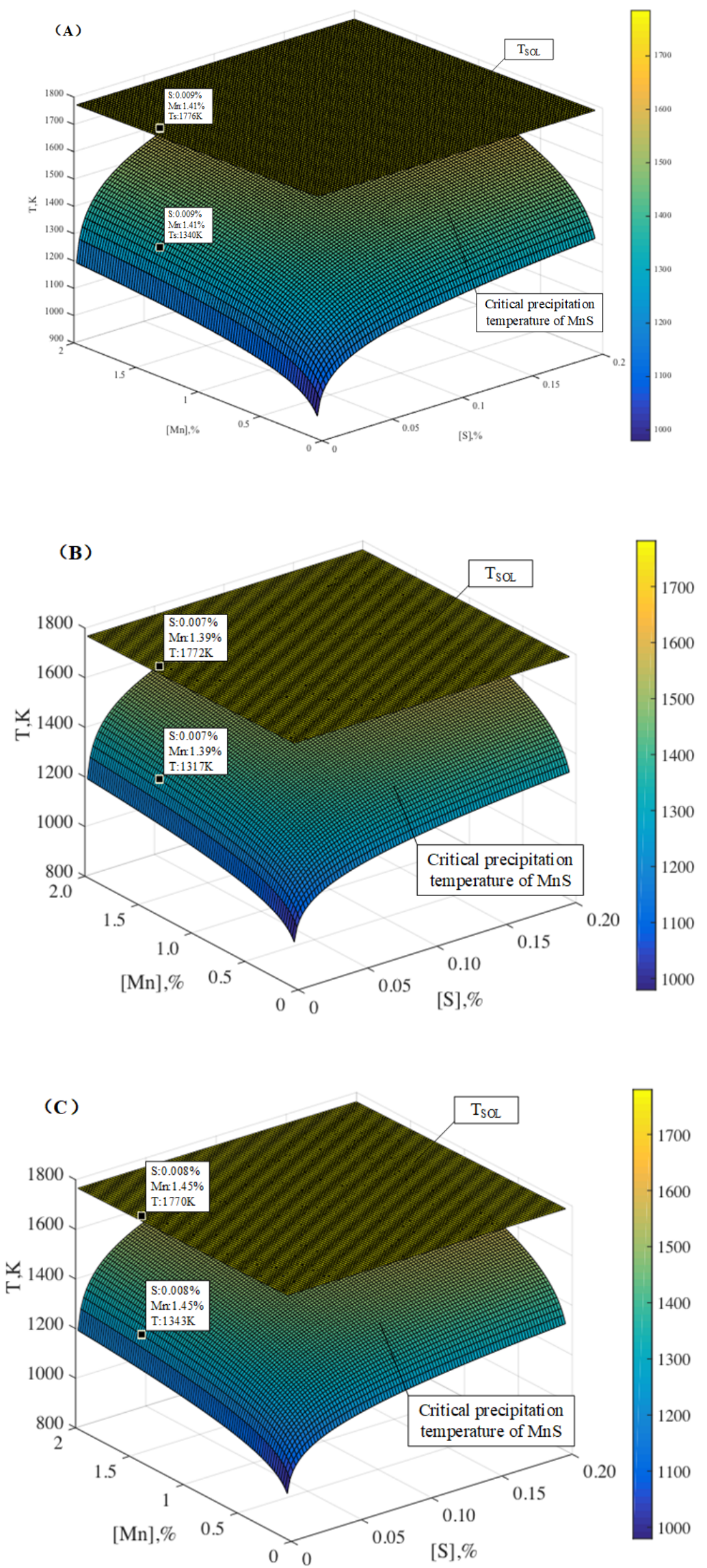

Figure 17: Changes in critical precipitation temperature of $\mathrm{MnS}$ and solidus temperature $\left(\mathrm{T}_{\mathrm{So}_{0}}\right)$ of the steel with Mn content and S content: A) Heat NO.1; B) Heat NO.2 and C) Heat NO.3. 
$32[\% \mathrm{P}]-31.5[\% \mathrm{~S}]-3.6[\% \mathrm{Al}]-1.5[\% \mathrm{Cr}]$

$$
-2[\% \mathrm{Mo}]-4[\% \mathrm{Ni}]-18[\% \mathrm{Ti}]-2[\% \mathrm{~V}]
$$

$\mathrm{T}_{\text {Sol }}\left({ }^{\circ} \mathrm{C}\right)=1536-334[\% \mathrm{C}]-12.3[\% \mathrm{Si}]-6.8[\% \mathrm{Mn}]-$ 124.5[\%P]-183.5[\%S]-4.1[\%Al]

$$
-1.4[\% \mathrm{Cr}]-4.3[\% \mathrm{Ni}]
$$

The concentration of $[\mathrm{S}]$ and $[\mathrm{Mn}]$ are calculated by Eq. (12) - (15) based on the Scheil model [22].

$$
\begin{aligned}
& \mathrm{T}=\mathrm{T}_{0}-\frac{T_{0}-T_{L}}{1-f_{s} \frac{T_{L}-T_{S O L}}{T_{0}-T_{S O L}}} \\
& f_{s}=\frac{T_{L}-T}{T_{L}-T_{S O L}} \\
& C_{L}=C_{0}\left(1-f_{s}\right)^{(K-1)} \\
& C_{S}=K C_{0}\left(1-f_{s}\right)^{(K-1)}
\end{aligned}
$$

Where $T_{0}, T_{S O L}, T_{L}, T$ are pure iron melting point (1809 K), solidus temperature, liquidus temperature and solid-liquid interface temperature, in $\mathrm{K}$. $C_{L}$ is the liquid concentration of a given solute element at the solid-liquid interface, $\mathrm{C}_{0}$ is the initial liquid concentration, $f_{\mathrm{s}}$ is the solid fraction, $\mathrm{K}$ is the equilibrium partition coefficient for that element,
$\mathrm{K}_{\mathrm{Mn}}=0.76$ [23], $\mathrm{K}_{\mathrm{S}}=0.05$ [23], $\mathrm{C}_{\mathrm{S}}$ is the solid concentration of a given solute element at the solid-liquid interface.

The variations of manganese and sulfur concentration with solid fraction in the steels are calculated and showed in Figure 18. The results show that there is MnS precipitation when the solid fraction is approximately 0.95 . And the $\mathrm{MnS}$ would be precipitated on the oxide during solidification process, which is agree well with the SEM/EDS results (Figure 1, Figure 2 and Figure 3). In the heat No.1, the oxide is mainly $\mathrm{Al}_{2} \mathrm{O}_{3}$, so the MnS mainly precipitated on it. (Figure 1 ). In the other heat, the oxide is mainly $\mathrm{MgO} \cdot \mathrm{Al}_{2} \mathrm{O}_{3^{\prime}}$, therefore, the cores of $\mathrm{MnS}$ are principally spinel (Figure 2 and Figure 3).

In conclusion, because of the large amount of smaller $\mathrm{MgO} \cdot \mathrm{Al}_{2} \mathrm{O}_{3}$ inclusions in the steel with magnesium, which is possible to provide nucleation cores (Figure 2 and Figure 3) for the precipitation of sulfides, the precipitation of sulfides at grain boundaries will be reduced and they will be dispersed. And the number of pure MnS decrease in the steel with magnesium (Figure 7, Figure 8 and Figure 9). At the same time, the sulfide with core

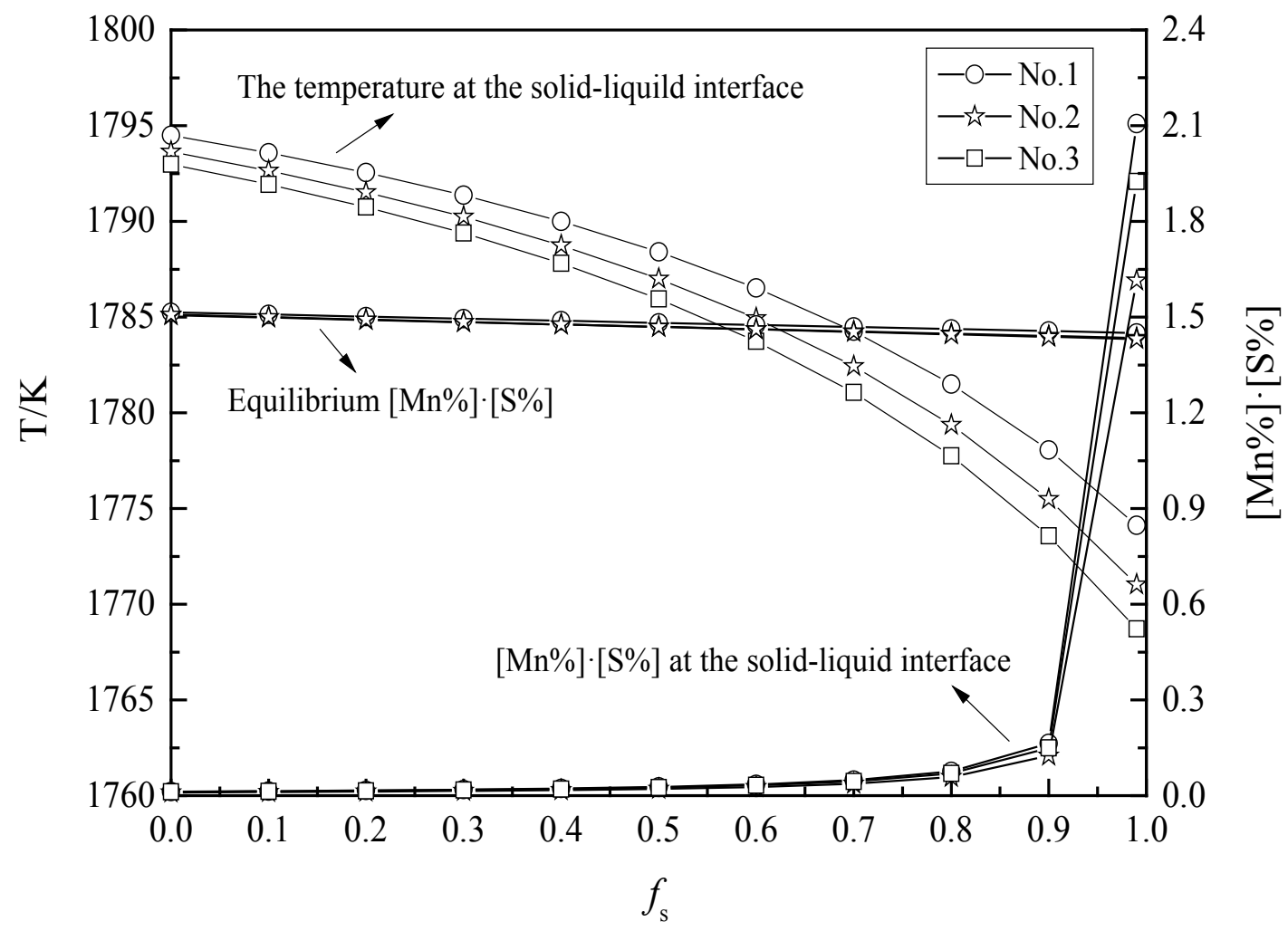

Figure 18: Changes in manganese and sulfur concentration with solid fraction. 
can further improve its capability of high temperature anti-deformation, and then further reduce its deformation degree during the rolling process. Accordingly, magnesium addition to the pipeline steel could improve its properties.

\section{Conclusion}

Effect of $\mathrm{Mg}$ treatment on inclusions of X65 pipeline steel is studied. By comparing and analyzing the composition and size of inclusions in non-magnesium-treated steel and magnesium-treated steel, the following conclusions are obtained:

(1)The oxide inclusions in non-magnesium-treated steel are mainly $\mathrm{Al}_{2} \mathrm{O}_{3}$ inclusions (93.85\%). The oxide inclusions in magnesium-treated steel are mainly $\mathrm{MgO} \cdot \mathrm{Al}_{2} \mathrm{O}_{3}$ inclusions. With the increase of magnesium content in the steel (from $0.0013 \%$ to $0.0024 \%$ ), the proportion of $\mathrm{MgO} \cdot \mathrm{Al}_{2} \mathrm{O}_{3}$ inclusions increase from $57.53 \%$ to $74.30 \%$, and the inclusion components are closer to $\mathrm{MgO} \cdot \mathrm{Al}_{2} \mathrm{O}_{3}$ spinel.

(2)The proportion of the inclusions in the magnesium-treated steel with a small particle size (1-5 $\mu \mathrm{m})$ is relatively high, besides, the proportion of inclusions in the range of 1-2 $\mu \mathrm{m}$ is higher than that in non-magnesium-treated steel. In the magnesium-treated steel, large particles (> $15 \mu \mathrm{m}$ ) inclusions are obviously reduced (the proportion is $0.21 \%$, and that in the two magnesium-treated steels are $0.10 \%$ and $0 \%$, respectively).

(3) Larger size inclusions are mainly $\mathrm{Al}_{2} \mathrm{O}_{3}$ inclusions and the inclusions near the low melting point. These inclusions are easy to polymerize and grow up, and if they fail to float to the surface of molten steel, they will remain in the steel. The particle size of the inclusions near the $\mathrm{MgO} \cdot \mathrm{A}$ $\mathrm{I}_{2} \mathrm{O}_{3}$ spinel is small, indicating that the MA spinel is difficult to polymerize in the molten steel, and the magnesium treatment can make inclusions small and dispersed in the steel.

(4) There are a large number of fine $\mathrm{MgO} \cdot \mathrm{Al}_{2} \mathrm{O}_{3}$ inclusions in the magnesium-treated steel, which can provide the nucleation core for the precipitation of sulfide, thus reduce the precipitation of sulfide at a grain boundary and disperse it. And the number of pure MnS decrease after magnesium treatment. At the same time, the magne- sium treatment can form ( $\mathrm{Mn} \cdot \mathrm{Mg}$ ) S composite sulfide in the steel, further reduce the deformation degree of sulfide during the rolling process, so as to avoid the form of long strips MnS in the final product and influence on the performance of pipeline steel.

\section{Acknowledgments}

The authors wish to express their application to the National Natural Science Foundation of China (No.51704200, No.51674172, No.51774208) and Jiangsu province Natural Science Fund (BK20150336, BK20150334) for providing financial support which enabled this study to be carried out.

\section{References}

1. Kim YM, Kim SK, Lim YJ, Kim NJ (2002) Effect of microstructure on the yield ratio and low temperature toughness of line pipe steels. ISIJ Int 42: 1571-1577.

2. Hardie D, Charles EA, Lopez AH (2006) Hydrogen embrittlement of high strength pipeline steels. Corros Sci 48: 4378-4385.

3. Wang XH, Li XG, Li Q, Huang FX, Li HB, et al. (2013) Control of string shaped non-metallic inclusions of CaO-Al2O3 system in X80 pipeline steel plates. Acta Metall Sinica 49: 553-561.

4. Domizzi G, Anteri G, Ovejero-Garcia J (2001) Influence of sulphur content and inclusion distribution on the hydrogen induced blister cracking in pressure vessel and pipeline steels. Corros Sci 43: 325-339.

5. Suito H, Inoue R (1996) Thermodynamics on control of inclusions composition in ultra-clean steels. ISIJ Int 36: 528-536.

6. Carneiro RA, Ratnapuli RC, Lins VD (2003) The influence of chemical composition and microstructure of API linepipe steels on hydrogen induced cracking and sulfide stress corrosion cracking. Mat Sci Eng: A 357: 104-110.

7. Tomita Y (1994) Effect of desulphurization and calcium treatments on the inclusion morphology of 0.4C-Cr-Mo-Ni steel. J Mater Sci 29: 2873-2878.

8. Higuchi Y, Numata M, Fukagawa S, Shinme K (1996) Inclusion modification by calcium treatment. ISIJ Int 36: S151-S154.

9. Wei LG, Peng Y, Xu WC, Shi YF (2010) Cause of X52 pipeline steel plate disqualification by ultrasonic flaw detection. The 14th National Symposium on steel quality and non-metallic inclusion control, China, 46-50. 
10.Li YD, Wang WJ, Zhu ZY, Wang XH, Liu JG, et al. (2008) Study on non-metallic inclusion control in pipeline steel. The 15th national steelmaking academic conference, China, 32-36.

11.Zhang WH, Chen XW, Wen K, Liu DC, Zhou QF (2009) Identification of nonmetallic inclusions and their influence on the properties of X80 pipeline steel. PTCA(PART: A PHYS. TEST) 45: 628-632.

12.Fu J, Yu YG, Wang AR, Chen BP, Sun WS (1998) Inclusion modification with $\mathrm{Mg}$ treatment for $35 \mathrm{CrNi}$ 3MoV steel. J Mater Sci Technol 14: 53-56.

13.Yang J, Yamasaki T, Kuwabara M (2007) Behavior of inclusions in deoxidation process of molten steel with in situ produced Mg vapor. ISIJ Int 47: 699-708.

14.Jiang ZH, Zhuang Y, Li Y, Li SJ (2013) Effect of modification treatment on inclusions in 430 stainless steel by Mg-Al alloys. J Iron Steel Res Int 20: 6-10.

15.Tsunekage N, Tsubakino H (2001) Effects of sulfur content and sulfide-forming elements addition on impact properties of ferrite-pearlitic microalloyed steels. ISIJ Int 41: 498-505.

16.Zhang TS, Wang DY, Liu CW, Jiang MF, Lu M, et al. (2014) Modification of inclusions in liquid iron by $\mathrm{Mg}$ treatment. J Iron Steel Res Int 21: 99-103.
17.Zhang TS, Wang DY, Jiang MF (2014) Effect of magnesium on evolution of oxide and sulphide in liquid iron at 1873K. J Iron Steel Res Int 21: 1073-1080.

18. Itoh H, Hino M, BanYa S (1997) Thermodynamics on the formation of spinel nonmetallic inclusion in liquid steel. Metall Mater Trans B 28: 953-956.

19.Huang XH (2004) Metallurgical principle. ( $3^{\text {rd }}$ edn), Metallurgical Industry Press, Beijing, China, 111.

20.Park JH, Lee SB, Gaye R (2008) Thermodynamics of the formation of MgO-Al2O3-TiO(x) inclusions in Ti-Stabilized $11 \mathrm{Cr}$ ferritic stainless steel. Metall Mater Trans B 39: 853-861.

21.Diederichs R, Bleck W (2006) Modelling of manganese sulphide formation during solidification, part I: description of MnS formation parameters. Steel Res Int 77: 202-209.

22.Won YM, Thomas BG (2001) Simple model of microsegregation during solidification of steels. Metall Mater Trans A 32: 1755-1767.

23. Ueshima $Y$, Mizoguchi S, Matsumiya T, Kajioka H (1986) Analysis of solute distribution in dendrites of carbon steel with $\delta / \gamma$ transformation during solidification. Metall Trans B 17: 845-859. 